\title{
KECERDASAN KEWIRAUSAHAAN (ENTREPRENEURIAL INTELLEGENCE) PETANI MUDA LULUSAN UNIVERSITAS PADJAJARAN
}

\author{
ENTREPRENEURIAL INTELLEGENCE OF YOUNG FARMERS \\ GRADUATED IN THE PADJAJARAN UNIVERSITY
}

\author{
Gema Wibawa Mukti*, Rani Andriani Budi Kusumo, Pandi Pardian \\ Program Studi Agribisnis, Fakultas Pertanian Universitas Padjadjaran \\ *Email: gema.wibawa@unpad.ac.id \\ (Diterima 27-08-2019; 01-11-2019)
}

\begin{abstract}
ABSTRAK
Pertanian adalah sektor usaha yang sangat bergengsi, karena sangat berperan dalam menyediakan bahan pangan bagi umat manusia. Namun rupanya hal ini tidak secara otomatis menarik perhatian masyarakat terutama generasi usia muda untuk menekuni bidang usaha pertanian, terutama lulusan Fakultas Pertanian. Generasi muda yang memilih berkarir di bidang pertanian dituntut untuk memiliki kecerdasan kewirausahaan yang baik sehingga dia dapat melihat suatu hambatan sebagai suatu tantangan yang positif. Tujuan Penelitian adalah mengetahui kecerdasan kewirausahaan dari lulusan Fakultas Pertanian yang memilih berkarir sebagai pelaku usaha di bidang pertanian. Metode penelitian dalam kajian ini adalah desain kualitatif. Observasi secara mendalam (Sugiyono, 2012) untuk melihat kecerdasan kewirausahaan yang dimiliki lulusan Fakultas Pertanian yang bergerak di usaha agribisnis. Hasil penelitian menunjukkan bahwa lulusan Fakultas Pertanian yang berusaha di bidang pertanian memiliki kecerdasan kewirausahaan seperti (1) memiliki keberanian mengambil risiko, (2) mampu mengenali kelebihan atau potensi dirinya, dimana mereka memiliki visi yang jelas dalam hidupnya, (3) memiliki kecerdasan emosi yang baik, (4) Selalu berorientasi pada proses dan hasil, (5) Adaptif terhadap perubahan, yaitu selalu mau belajar, berubah dan berkembang mengikuti perubahan pasar dan lingkungan, (6) Tidak pernah berhenti untuk berinovasi dalam perjalanan usahanya, (7) Mampu senantiasa berkolaborasi dengan pihak lain dan bekerjama secara positif satu sama lain sehingga semua pihak dapat berkembang dan sukses secara bersama - sama, (8) Selalu membangun jaringan usaha (silaturahmi) dengan mitra dan stakeholder yang terkait dengan usahanya, (9) Membiasakan selalu memberikan manfaat kepada lingkungan sekitar, berbagi dan maju bersama sehingga selalu memiliki semangat positif untuk sukses.
\end{abstract}

Kata kunci: Kewirausahaan, Kecerdasan Kewirausahaan, Bisnis, Pertanian, Kolaborasi

\begin{abstract}
Agriculture is a very prestigious business sector, because it plays an important role in providing food for humanity. But apparently this does not automatically attract the attention of the community, especially the younger generation to pursue the field of agricultural business, especially graduates of the Faculty of Agriculture. Young people who choose a career in agriculture are required to have good entrepreneurial intelligence so that they can see an obstacle as a positive challenge. The purpose of this study was to determine entrepreneurial intelligence from graduates of the Faculty of Agriculture who chose a career as a business actor in agriculture. The research method in this study is a qualitative design. In-depth observation (Sugiyono, 2012) to see entrepreneurial intelligence possessed by graduates of the Faculty of Agriculture engaged in agribusiness. The results showed that graduates of the Faculty of Agriculture who are engaged in agriculture have entrepreneurial intelligence such as (1) having the courage to take risks, (2) being able to recognize their strengths or potentials, where they have a clear vision in life, (3) having emotional intelligence good, (4) Always oriented to the process and results, (5) Adaptive to change, which is always willing to learn, change and develop following changes in markets and the environment, (6) Never stop innovating in the course of its business, (7) Able to always collaborate with other parties and work together
\end{abstract}


positively with each other so that all parties can develop and succeed together - (8) Always build a business network (friendship) with partners and stakeholders related to their business, (9) Getting used to always provide benefits to the environment, sharing and advancing together so that they always have a positive spirit for success.

Keywords: Entrepreneurship, Entrepreneurship Intelligence, Business, Agriculture, Collaboration

\section{PENDAHULUAN}

Sektor Pertanian masih menjadi primadona bagi masyarakat Indonesia, dimana sebagian besar masyarakat masih mengandalkan pertanian sebagai mata pencaharian mereka. Data BPS (2015), menunjukkan bahwa jumlah tenaga kerja di sektor pertanian menurun sebesar 3,13\%, mengalami penurunan dari 38,97 juta orang menjadi 37,75 juta orang. Menurut Kementerian Pertanian (2015), penurunan ini merupakan sesuatu hal yang wajar dan alamiah ketika sektor lain (non pertanian) mengalami kemajuan. Masyarakat golongan usia muda (18-40 tahun) lebih memilih sektor perdagangan dan jasa dibandingkan dengan sektor pertanian. Masyarakat yang berusia di atas 40 tahun biasanya masih memilih pertanian sebagai mata pencaharian utama mereka sehingga masih bertahan sebagai petani.

Pertanian adalah sektor usaha yang sangat bergengsi, karena sangat berperan dalam menyediakan bahan pangan bagi umat manusia. Namun rupanya hal ini tidak secara otomatis menarik perhatian masyarakat terutama generasi usia muda untuk menekuni bidang usaha pertanian.

Generasi muda mulai asing dengan pertanian, terlihat dengan semakin berkurangnya anak muda yang bergerak di bidang pertanian. Sembara (2009) menjelaskan ada beberapa hal yang menyebabkan pertanian tidak menjadi bagian dari masa depan mereka, diantaranya adalah: (1) masyarakat belum mengenal pertanian secara spesifik, dimana masyarakat mengenal pertanian adalah hanya kegiatan bercocok tanam saja, (2) masih adanya stigma negatif terhadap pertanian, sehingga orang tua cenderung melarang anaknya untuk menjadi seorang "petani", (3) adanya persepsi bahwa petani itu identik dengan desa dan kemiskinan.

Fakultas Pertanian Universitas Padjadjaran setiap tahunnya rata-rata meluluskan 350-400 orang. Potensi ini tentunya memberikan harapan yang besar bagi pertanian Indonesia pada umumnya dan Jawa Barat khususnya, bahwa Sarjana Pertanian sebagai generasi penerus sektor pertanian semakin banyak secara kuantitas dan juga kualitas. Berdasarkan data Tracer 
Study Fakultas Pertanian UNPAD, rata-rata lulusan yang berwirausaha dan bekerja di sektor pertanian adalah sekitar 10-15\% dari total lulusan.

Berdasarkan fakta di atas, menarik untuk melihat kecerdasan kewirausahaan seperti apa yang mereka miliki sehingga mereka memilih untuk berwirausaha di bidang agribisnis dengan segala risiko yang mungkin akan mereka terima. Harapannya tulisan ini dapat memberikan gambaran atau juga inspirasi bagi para lulusan lainnya bahwa pertanian adalah bidang usaha yang dapat memberikan kepastian masa depan bagi para generasi muda lulusan Fakultas Pertanian Unpad.

\section{METODE PENELITIAN}

Metode penelitian dalam kajian ini adalah desain kualitatif. Observasi secara mendalam (Sugiyono, 2012) untuk melihat kecerdasan kewirausahaan yang dimiliki lulusan Fakultas Pertanian yang bergerak di usaha agribisnis. Informan dalam penelitian ini adalah lulusan Fakultas Pertanian Unpad angkatan 2008-2012 (lulus tahun 2012-2016) yang memilih untuk berwirausaha di bidang agribisnis setelah mereka lulus. Informan dalam penelitian ini adalah sebanyak 30 orang alumni Fakultas Pertanian yang berwirausaha di bidang agribisnis.
Rancangan Analisis Data menggunakan metode deskriptif, yaitu untuk menjelaskan kecerdasan kewirausahaan yang dimiliki oleh lulusan Fakultas Pertanian Universitas Padjadjaran, sehingga mereka memilih untuk berwirausaha di bidang keilmuan mereka sendiri, yaitu di bidang pertanian.

\section{HASIL DAN PEMBAHASAN}

\section{A. Kewirausahaan}

Pertanian di Indonesia identik dengan kemiskinan, perdesaan dan ketinggalan zaman. Stigma tersebut muncul di masyarakat sehingga minat masyarakat terhadap sektor pertanian semakin menurun. Petani secara umum masih berorientasi produksi, yaitu memfokuskan usahanya dalam budidaya tanaman, untuk kemudian mereka menggantungkan harapan kepada pedagang untuk membeli hasil panen mereka. Sebagian petani merupakan petani subsisten, yaitu sistem pertanian yang tujuan utamanya untuk memenuhi kebutuhan sendiri dan keluarganya, untuk kemudian jika ada kelebihan dapat dijual ke pihak lain. Sebagian petani memiliki orientasi ke arah bisnis, senantiasa berubah mengikuti pasar dan melakukan kolaborasi dengan petani atau pelaku usaha lainnya sehingga usaha 
mereka dapat bertahan dan bahkan berkembang.

Dalam perjalanannya, sikap kewirausahaan dalam kegiatan bisnis pertanian saat ini tampaknya telah menjadi suatu keniscayaan, di tengah segala perubahan yang serba cepat. Gede Mekse (2016), menjelaskan bahwa kewirausahaan menjadi faktor penting bagi manusia karena tingkat kebutuhan yang senantiasa meningkat dan perubahan lingkungan yang terus terjadi. Perubahan tersebut berlangsung di semua sendi kehidupan manusia, termasuk di sendi pertanian. Petani yang dapat bertahan adalah petani yang mampu beradaptasi dengan perubahan tersebut. Geofrey and Meredith (1996) menjelaskan bahwa wirausahawan adalah orang-orang yang memiliki orientasi terhadap proses atau usaha (tindakan), memiliki motivasi tinggi untuk mewujudkan mimpi atau tujuannya serta berani mengambil risiko dalam menjalani pilihannya tersebut.

Seorang individu yang memiliki jiwa kewirausahaan, pada umumnya memiliki sikap percaya diri akan kemampuannya, selalu berorientasi pada aktivitas usaha untuk menghasilkan sesuatu, mandiri, selalu memiliki inisiatif yang kuat terhadap sesuatu aktivitas dan mengedepankan kerja keras untuk mencapainya. Tuntutan kebutuhan hidup yang harus selalu dipenuhi membuat wirausahawan selalu kreatif dan inovatif dalam menghadapi suatu permasalahan dalam hidupnya.

Tindakannya tersebut tidak lepas dari sikap seorang wirausahawan yang selalu berorientasi pada masa depan, sehingga mereka selalu memiliki keinginan yang kuat untuk selalu lebih baik dari sebelumnya.

\section{B. Kecerdasan Kewirausahaan Sarjana Pertanian Unpad Yang Berusahatani}

Kecerdasan Kewirausahaan atau sering disebut Entrepreneurial Intellegence, adalah bagian dari konsep manajemen diri, yaitu suatu proses dimana seseorang dapat mengatur kehidupannya, sehingga kehidupannya secara sosial, ekonomi dan emosional dapat tertata secara baik dan mampu memberikan kebahagiaan kepada orang yang menjalankannya.

Kecerdasan seseorang dalam kewirausahaan adalah pola pikir yang dimiliki seseorang dalam mengelola dirinya untuk memilih suatu pekerjaan. Patton (1998) menjelaskan bahwa kecerdasan kewirausahaan adalah kecerdasan emosi di "tempat kerja" untuk mencapai suatu tujuan, membangun suatu proses kerja yang produktif dan meraih suatu keberhasilan dalam usahanya tersebut. Goleman (2009) 
mengatakan bahwa kecerdasan emosional dalam aspek kewirausahaan adalah bagaimana seseorang memotivasi dirinya sendiri sehingga dapat memperoleh keberhasilan dalam kegiatan kewirausahaannya tersebut.

Konsep Kecerdasan Kewirausahaan secara umum adalah dorongan serta kemampuan yang dimiliki oleh seseorang dalam memanfaatkan kreativitas dan kekuatan yang ada dalam dirinya untuk memulai suatu usaha atau bisnis atau kegiatan yang dapat memberikan nilai ekonomi bagi dirinya. Kecerdasan kewirausahaan adalah kemampuan seseorang dalam mengenali potensi dirinya, kemampuan dirinya, kelebihan serta kekurangan dirinya untuk kemudian semua itu menjadi sumberdaya bagi dirinya untuk menjalankan suatu usaha.

Manusia cenderung bergerak ke arah kenyamanan diri, kebahagiaan dan kemudahan dalam hidup. Manusia secara naluriah menghindari kesulitan dalam hidup. Proses pemilihan karier dipengaruhi banyak faktor, seperti latar belakang, tingkat pendidikan, kondisi sosial ekonomi, prinsip diri dan lain sebagainya. Apabila kita berbicara tentang karir atau pekerjaan, tentu kita akan melihat latar belakang pendidikan yang terakhir. Jika kita menyebut Sarjana Pertanian, tentunya pikiran kita langsung mengarah pada orangorang yang akan ber-usaha atau bekerja di bidang pertanian. Pandangan masyarakat terhadap pertanian di tahun 2017 ini masih belum banyak berubah dari sebelumnya, dimana masyarakat masih memandang pertanian adalah bidang usaha yang berisiko tinggi, identik dengan kemiskinan, berkutat di subsistem on farm, menjadi orang desa dan pandangan-pandangan negatifnya terhadap pertanian.

Banfe (1991) menjelaskan bahwa mitos berwirausaha tidak memiliki prospek menjanjikan adalah sesuatu yang tidak benar dan di masa depan mitos seperti ini harus mulai dikikis, terutama di kalangan Sarjana atau lulusan Perguruan Tinggi. Fakultas Pertanian Universitas Padjadjaran, semenjak tahun 2008 hingga saat ini mulai mendorong mahasiswa untuk berwirausaha di bidang pertanian. Perubahan kurikulum terus dilakukan agar lulusan-lulusan Fakultas Pertanian "bersedia" untuk berwirausaha di bidang Pertanian. Kajian utama dalam penelitian ini adalah melihat kecerdasan kewirausahaan lulusan-lulusan yang berbisnis di bidang pertanian. Mereka pada umumnya memiliki karakteristik unik yang berbeda dengan lulusan pada umumnya, yaitu: 


\section{Mengenali Kelebihan Diri}

Salah satu temuan menarik dalam penelitian ini adalah, lulusan yang memilih agripreneurship sebagai pilihan hidup mereka adalah lulusan yang memiliki IPK di bawah 3,25. Secara kemampuan akademik, mereka tergolong pada golongan mahasiswa yang tidak terlalu istimewa, namun rata-rata dari mereka aktif dalam kegiatan-kegiatan kemahasiswaan. Setelah lulus, mereka memahami bahwa dirinya lebih menyukai kegiatan-kegiatan yang berhubungan dengan aktivitas di lapangan yang dinamis. Hal ini terkait dengan kebiasaan mereka semasa mahasiswa yang selalu berhubungan dengan aktivitasaktivitas yang dinamis. Pemahaman diri menjadi sesuatu yang penting bagi seorang lulusan perguruan tinggi dalam menghadapi dunia usaha atau dunia kerja. Memahami kelebihan diri atau potensi diri menjadi sesuatu yang harus dimiliki oleh lulusan Fakultas Pertanian, agar mereka dapat memutuskan apa yang akan mereka lakukan setelah lulus. Lulusan yang berwirausaha sangat memahami bahwa dirinya memiliki kompetensi dalam berwirausaha, berani mengambil risiko usaha dan memiliki keinginan untuk menentukan masa depan mereka sendiri.

\section{Kecerdasan Emosional}

Tantangan seorang lulusan Fakultas Pertanian ketika berniat untuk bewirausaha, tidak hanya datang dari faktor eksternal, namun juga datang dari faktor internal. Kemampuan menghadapi "ketidakbiasaan" dari lingkungan dan juga diri sendiri memperlihatkan kecerdasan kewirausahaan dari seorang Sarjana Pertanian. Beberapa kecerdasan kewirausahaan yang dimiliki adalah

a. Memahami bahwa dirinya memiliki hard skills yang berhubungan dengan pertanian, baik dari sisi onfarm maupun dari sisi off farm (pemasaran). Kemampuan tersebut menjadi modal bagi dirinya untuk memulai usaha/bisnis pertanian.

b. Memahami bahwa bisnis pertanian tidak hanya sebatas kegiatan berkebun di lahan, namun bisnis di semua subsistem agribisnis, mulai dari penunjang, onfarm, offfarm, pemasaran dan pengolahan produk pertanian.

c. Memahami bahwa manusia pasti membutuhkan pangan sebagai kebutuhan utama untuk hidup. Mereka mampu melihat kondisi sekarang dimana petani semakin berkurang, lahan pertanian semakin berkurang, namun jumlah penduduk semakin meningkat. Seorang lulusan yang 
memiliki jiwa entrepreneur, melihat kondisi ini sebagai suatu peluang yang sangat potensial untuk ditekuni.

d. Melihat pandangan negatif masyarakat terhadap usaha di bidang pertanian sebagai suatu tantangan positif untuk membuktikan diri bahwa usaha di bidang pertanian adalah menguntungkan dan bisa memberikan penghidupan yang layak dan menjanjikan di masa yang akan datang.

e. Kebanggaan sebagai lulusan Fakultas Pertanian yang aktif di organisasi yang berkaitan erat dengan pertanian, mendorong mereka untuk kembali berkiprah di bidang yang sama setelah lulus.

f. Mahasiswa yang aktif selama kuliah, baik di lembaga kemahasiswaan atau di komunitas Pertanian cenderung meneruskan kegiatannya tersebut ke jenjang yang lebih profesional dibandingkan dengan pada saat kuliah.

g. Pembuktian diri terhadap orang tua untuk bisa berhasil di bidang pertanian mendorong Sarjana Pertanian untuk ber-agripreneurship.

h. Mampu memanfaatkan kemampuan berkomunikasi dalam bisnis pertanian yang mereka dapat di perkuliahan, yaitu mampu untuk menjalin komunikasi secara baik dengan para alumni/ komunitas yang lebih berpengalaman sehingga semangat mereka untuk berbisnis di bidang pertanian dapat terjaga dan terpupuk dengan baik.

\section{Berani Mengambil Risiko}

Keberanian mengambil keputusan untuk menjadi seorang pengusaha di bidang pertanian merupakan suatu keberanian dalam mengambil risiko. Seorang Sarjana Pertanian memahami bahwa bisnis pertanian adalah bisnis yang sangat tergantung kepada alam dan sangat dibatasi oleh waktu. Produk pertanian mudah rusak, sehingga dalam penanganannya dibutuhkan effort yang lebih detail, sabar, tekun dan komitmen tinggi. Ketika misalnya ada kesalahan dalam proses pengiriman, maka produk akan menurun kualitasnya dan harga jual juga menurun.

Banyaknya lulusan pertanian yang berkarir di luar bidang pertanian, bukan karena mereka tidak memahami pertanian, namun karena mereka sangat memahami karakteristik produk pertanian, sehingga mereka memutuskan untuk berkarir di luar bidang pertanian. Lulusan yang mengetahui kondisi tersebut, namun mereka tetap mengambil keputusan untuk berusaha di bidang pertanian, tentunya memiliki keberanian dalam mengambil risiko tersebut. 


\section{Berorientasi pada Proses dan Hasil}

Pada zaman informasi digital saat ini, manusia sangat mudah untuk mengakses suatu informasi yang dibutuhkan dengan sangat cepat. Kondisi ini ternyata secara tidak langsung mendorong terjadinya suatu perubahan sosial di masyarakat. Generasi muda saat ini cenderung untuk mendapatkan sesuatu secara cepat atau instan. Dalam berkarir, baik sebagai wirausahawan atau sebagai karyawan, kebiasaan instan ini sudah menjadi suatu hal yang biasa bagi generasi muda tersebut. Dalam berwirausaha, seorang calon pengusaha tentunya harus sangat memahami bahwa diperlukan suatu proses berjenjang bagi seseorang untuk memulai usaha hingga mencapai fase kesuksesan pada waktunya nanti.

Lulusan Fakultas Pertanian saat ini cenderung lebih memilih untuk menjadi karyawan karena akan cepat mendapatkan hasil/gaji. Setelah mereka bekerja selama satu bulan, maka mereka mendapatkan salary atas hasil kerja nya. Lulusan yang memilih berwirausaha melihat bahwa uang adalah sangat penting, namun pengembangan diri di dalamnya juga penting. Dalam suatu start up bisnis, tidak ada jaminan bahwa bisnis tersebut akan langsung menghasilkan profit bagi pelakunya.
Hal ini tentunya menjadi suatu tantangan tersendiri bagi para lulusan Fakultas Pertanian, karena mereka harus mulai usaha dengan berproses tahap demi tahap. Dalam bisnis, mereka harus merasakan bagaimana menjual, memproduksi, berhubungan dengan konsumen, supplier, menghadapi lingkungan dan tantangan lainnya. Namun ini proses yang mereka jalani untuk mencapai tujuan untuk meraih profit dan kesuksesan dalam bisnisnya. Lulusan yang memiliki kecerdasan kewirausahaan yang baik, tentunya akan memandang proses ini sebagai bagian dari kehidupan yang harus dilalui dengan sabar dan tekun.

\section{Adaptif Terhadap Perubahan}

Perubahan adalah suatu keniscayaan yang harus dihadapi oleh setiap manusia. Dalam aktivitas bisnis, perubahan sudah tentu pasti terjadi. Perubahan dalam bisnis diantaranya perubahan pasar, perubahan teknologi, perubahan supplier, perubahan model bisnis dan lain sebagainya. Seorang wirausahawan tentunya harus mampu beradaptasi terhadap segala perubahan yang terjadi jika mereka ingin usahanya terus berkembang.

Perubahan saat ini terasa sangat cepat apabila dibandingkan dengan 5-10 tahun yang lalu. Kemudahan akses informasi menjadin salah satu penyebab perubahan 
dalam dunia usaha sangat cepat. Konsumen modern sebagai seorang manusia tentu akan selalu membutuhkan pangan, namun preferensi atau pengetahuan konsumen tentang pangan yang aman dan berkualitas terus berkembang. Konsumen mudah mengakses informasi mengenai pangan yang aman dan ini menjadi kebutuhan sekaligus gaya hidup konsumen saat ini. Sarjana Pertanian yang berbisnis produkproduk pertanian tentunya sangat memahami kondisi seperti ini, sehingga mereka selalu menyesuaikan diri dengan perubahan-perubahan yang terjadi. Kemampuan untuk beradaptasi ini tentunya harus didukung oleh kecerdasan kewirausahaan yang baik, karena butuh inisiatif, kemandirian yang kuat agar mampu mengikuti arus perubahan yang terjadi.

\section{Kreatif, Inovatif dan Kolaboratif}

Seorang wirausahawan tentu akan selalu berhadapan dengan berbagai masalah, baik itu dalam pasar, produksi, komunikasi bisnis, jaringan, manajemen usaha dan lain sebagainya. Dalam menghadapinya, seorang wirausahawan harus memiliki kemampuan untuk mengelola diri dan lingkungannya (sumber daya) sehingga dapat menjawab segala permasalahan yang ada. Kreatif adalah sifat atau kemampuan yang harus dimiliki oleh seorang wirausahawan, karena di dalamnya terkandung proses mental sehingga menghasilkan gagasan atau suatu produk yang dibutuhkan oleh masyarakat (Gallagher, 2003). Proses mental ini berkaitan dengan kemauan seseorang untuk senantiasa belajar, mencoba dan mengambil risiko untuk gagal dalam menghasilkan suatu produk.

Seorang Sarjana Pertanian yang bergerak sebagai wirausahawan di bidang pertanian juga memiliki sifat inovatif. Fontana (2009), menjelaskan bahwa inovasi adalah kesuksesan dalam bidang ekonomi karena diperkenalkannya cara baru atau kombinasi baru dari cara-cara lama untuk merubah input menjadi output yang mampu menciptakan perubahan besar dalam hubungan antara nilai guna dan harga yang ditawarkan kepada konsumen. Dalam menjual produk sayuran yang memiliki karakteristik yang unik yaitu mudah rusak dan suatu produk yang biasa dimakan oleh masyarakat, maka diperlukan suatu usaha yang inovatif agar konsumen bersedia untuk membeli produk pertanian dengan perasaan senang dan membelinya dengan harga yang layak. Inovasi yang diberikan oleh seorang Sarjana Pertanian adalah dengan menjual produk sayuran yang berkualitas premium dengan harga yang proporsional. Konsumen modern saat 
ini tentu akan membeli produk yang menurut mereka berkualitas dan dapat memberikan manfaat untuk mereka. Produk sayuran dijual dengan konsep langsung dari petani, berkualitas dan segar. Informasi tersebut disampaikan kepada konsumen melalui kemasan yang menarik dan informatif (inovatif) kepada konsumen, sehingga pembeli merasa nyaman dan layak untuk membeli produk tersebut. Para wirausahawan ini juga menyadari bahwa, sumberdaya yang mereka miliki sangat terbatas. Sewa lahan yang mahal, harga tanah yang mahal dan juga biaya investasi untuk berkebun yang besar, mendorong mereka untuk melakukan kolaborasi dengan petani, sehingga mereka tetap mendapatkan produk-produk pertanian untuk mereka jual kepada konsumen modern di wilayah perkotaan. Untuk lulusan yang melakukan usahatani, mereka juga melakukan komunikasi dan kolaborasi dengan teman-teman alumni yang bergerak di hilir.

Pemahaman bahwa berbisnis memerlukan mitra dan lebih baik apabila mitranya adalah pihak yang sudah dikenal atau dipercaya sangat dipahami oleh para lulusan tersebut. Kesamaan almamater dan nasib juga membuat kolaborasi mereka dapat berjalan dengan baik dan kerjasama bisnis yang mereka jalankan didasarkan atas kepercayaan dan juga keinginan untuk maju dan sukses bersama. Perilaku ini menunjukkan kecerdasan kewirausahaan yang dimiliki oleh para alumni atau lulusan Fakultas Pertanian sehingga mereka mampu berusaha, bertahan, berkembang dan sukses bisnis di bidang pertanian.

\section{KESIMPULAN DAN SARAN}

Berkarir di sektor pertanian, bagi sebagian masyarakat dianggap tidak menjanjikan dan identik dengan kemiskinan. Ironisnya, lulusan Fakultas Pertanian yang dianggap memiliki kompetensi dalam bidang pertanian lebih memilih sektor pertanian sebagai pilihan karirnya. Namun demikian, masih terdapat sebagian kecil lulusan yang memilih untuk berwirausaha agribisnis dan menjadikannya sebagai pilihan hidup mereka. Mereka memiliki kecerdasan kewirausahaan yang baik, sehingga mereka dapat menjadikan segala hal negatif tentang pertanian menjadi tantangan dan peluang yang dapat memberikan penghidupan yang layak bagi mereka. Kecerdasan kewirausahaan yang dimiliki oleh mereka diantaranya adalah (1) memiliki keberanian mengambil risiko, (2) mampu mengenali kelebihan atau potensi dirinya, dimana mereka memiliki visi yang jelas dalam hidupnya, (3) memiliki kecerdasan emosi yang baik, (4) Selalu 
berorientasi pada proses dan hasil, (5) adaptif terhadap perubahan, yaitu selalu mau belajar, berubah dan berkembang mengikuti perubahan pasar dan lingkungan, (6) tidak pernah berhenti untuk berinovasi dalam perjalanan usahanya, (7) mampu senantiasa berkolaborasi dengan pihak lain dan bekerjama secara positif satu sama lain sehingga semua pihak dapat berkembang dan sukses secara bersama-sama, (8) Selalu membangun jaringan usaha (silaturahmi) dengan mitra dan stakeholder yang terkait dengan usahanya, dan (9) membiasakan selalu memberikan manfaat kepada lingkungan sekitar, berbagi dan maju bersama sehingga selalu memiliki semangat positif untuk sukses.

\section{DAFTAR PUSTAKA}

Banfe, C. 1991. Entrepreneur-from Zero to Hero. New York: Van Nostrand Reinhold.

Crow and Crow. (1973). An Outline of Psicology (Terjemahan Z. Kazijan). Surabaya: PT Bina Ilmu

Fontana, A. 2009. Innovate We Can!. How to Create Value Through Innovation in Your Organization and Society. Jakarta: PT Gramedia Widiasarana Indonesia.
Gallagher, Timothy J. dan Joseph D. Andrew, 2003. Financial Management: Principles and Practice, Third Edition, Prentice Hall, USA.

Gede Mekse Korri Arisena (2016). Konsep Kewirausahaan Pada Petani Melalui Pendekatan Structural Equation Model (SEM). Jurnal Agribisnis dan Agrowisata, 5(1): 1-15.

Geoffrey, G. Meredith, et. al. (1996). Kewirausahaan Teori dan Praktek. Jakarta: PT. Pustaka Binaman Presindo.

Goleman, D. (2009). Emotional Intelligence. Kecerdasan Emosional Mengapa EI Lebih Penting daripada IQ. (Terjemahan T. Hermaya). Jakarta: PT Gramedia Pustaka Utama.

Hurlock, Elizabeth. B. 1980. Psikologi Perkembangan. Terjemahan Istiwidayanti dan Soedjarwo. "Masa Remaja". Jakarta: Penerbit. Erlangga.

Patton, Parry. 1998. EQ - Kecerdasan Emosional Membangun Hubungan; Jalan Menuju Kebahagiaan dan Kesejahteraan. Jakarta: PT. Pustaka Delapratasa.

Sembara, R. 2009. Menurunnya Minat Siswa dalam Studi Pertanian. Melalui:http://www.repository.ipb.ac .id/.../PKM-GT09.Penurunan-MinatRayIPB.html [12/08/12].

Sugiyono. (2012). Memahami Penelitian Kualitatif'. Bandung : ALFABETA.

Witherington, H. C. (1999). Psikologi Pendidikan. Jakarta: Aksara Baru. 